Published in Review of African Political Economy (2018), DOI: 10.1080/03056244.2018.1484351.

\title{
The Rise of Oligarchy in Ethiopia: The Case of Wealth Creation since 1991
}

Tefera Negash Gebregziabher and Wil Hout

\section{Introduction}

In the summer of 1993, the Ethiopian People's Revolutionary Democratic Front (EPRDF) announced that a number of its party members were 'expelled because they have acted in their own interest' (Indian Ocean Newsletter, 24 July 2016). Almost a déjà vu, the central committee of the front has made a similar claim some twenty-three years later, indicating it identified abuse of office for private gains as one of the challenges the developmental democratic system has been facing' (FBC, 22 August 2016). At the same time, the regime lauds its achievements of economic growth, ethnolinguistic self-determination and formal political participation.

It is not, however, a sporadic abuse of power by a few members of the elite that characterises the political economy of post-1991 Ethiopia, but a systematic emergence of oligarchic politics that the ruling party has used to establish and consolidate its position. The TPLF, the core of the EPRDF, leads the rest of the parties in the front in building business empires. Thus, the Ethiopian economy (or more precisely, its booming sectors) is not just dominated by business elites, but also the front's political elites and 'other friends of the TPLF' who were allowed to the heights of fortune in the country. This briefing piece attempts to unpack the domains and processes of oligarchy in the changing political economy landscape of the Ethiopian state.

The state's role in Africa has spurred substantial debate and some argue that it was through 'access to the state' that political influence was acquired (Kawabata 2006, Van Hoyweghen and Smis 2002). For Cheru $(1989,12)$ 'the real issue in Africa is not the degree to which the state intervenes in economic matters, but on whose behalf it intervenes'. In EPRDF's Ethiopia, the 'comeback of ethnic politics', the rise of 'a post-Marxist-Leninist vanguard party' to power, and 'economic dynamism' in consecutive years of economic growth have given the period since 1991 a special place in contemporary African politics (Hagmann and Abbink, 2011, 579).

\section{Wealth creation and concentration in Ethiopia}

Taking these dynamics into account, it is imperative to investigate the nature of wealth concentration in a country where the regime boasts annual GDP growth of 11 percent for over a decade (MoFED, 2014). According to a long-serving State Minister, responsible for economic development and national planning, the Ethiopian economy has gone through two phases over the last 25 years (Abraham Tekeste, interview 28 April 2016). The first ten years were an era of recovery ${ }^{1}$ and the later 15 were a period of shared growth. Ethiopia's economic growth has been 
hailed as miraculous and received appreciation from international financial institutions such as the World Bank and International Monetary Fund.

Although Ethiopia's GDP growth figures are contested, and the IMF estimated annual growth at 7 to 8 rather than 11 percent (EUI, 2012, 8), observers agree that there has been real GDP growth through expansion of the construction and service sectors (Seid et al., 2015). While agriculture, which accounted for 42.9 percent of GDP in 2012/13 (EIC, 2104), continues to be important as a major source of foreign currency and employment, its contribution to economic growth has become more limited.

The Ethiopian Investment Commission reported that the service sector accounted for 45.2 percent of GDP in fiscal year 2012/13 (EIC, 2014). The major subsectors responsible for GDP growth include commerce (wholesale and retail trade, hotels and restaurants) and public services (public administration and social services; education; health and social work). The World Bank (2016) estimated that the service sector accounted for about half of economic growth generated between 2004 and 2014, and that it has become the second biggest employer; yet, the sector's contribution to poverty reduction is modest.

The construction sector - especially the roads, water supply and irrigation, power and other public works subsectors - is growing fast: the Minister for Construction Minister claims that the sector had an annual growth rate of 12.43 percent and is currently contributing over 5 percent to Ethiopia's GDP (Reporter, 17 December 2016; World Bank, 2016). According to the National Bank of Ethiopia (2014/15 Annual report), construction accounted for over half of industrial production in fiscal year 2015/16.

\section{Rise of Oligarchy, 1991-2016}

The nexus between wealth creation and political power is particularly important in the booming sectors of construction, wholesale and retail trade. Ethiopia's economic growth has been fuelled by massive public investment and inflows of foreign aid and loans. The proceeds of growth have been captured by a minority of politically well-connected businesses and politico-military elites, leading to the emergence of oligarchic politics. This confirms Winters' $(2011,18)$ expectation that wealth 'sets in motion the politics and processes of oligarchy'. Oligarchy produces the politics of wealth defence, which can take different shapes, from involvement in government to coercive practices (Winters, 2011; Åslund, 2007).

Both classical and recent contributions focus the analysis of oligarchy on how wealth is created and defended, as well as on the direct and indirect rule exercised by the wealthy. In their study of Ukrainian oligarchs, Markus and Charnysh (2017) have shown how oligarchs can be flexible while politicians are subjected to electoral battles and their consequences. They concluded that 'oligarchs do not expire - politicians do', pointing out that support of parties and media ownership mask and magnify the influence of oligarchs. The context of oligarchic politics in Ethiopia offers another dimension to the argument. The direct dimension of rule seems deeply entrenched and multiple networks tie the ruling party to the emerging rich. Privatisation, land deals, phoney shareholdings and corruption are the main mechanisms of oligarchisation in the booming sectors. 


\section{Privatisation}

Privatisation was the first mechanism of wealth concentration that tilted the economic playing field under the EPRDF regime. When the regime came to power in 1991, the state owned 211 manufacturing firms (CSA, 2003; Demissie, 2008). Since the start of the privatisation programme, more than 280 enterprises were privatised using different modalities. ${ }^{2}$ Data show that the primary beneficiaries of the privatisation scheme were the Saudi-Ethiopian business mogul, Sheik Mohammed Hussein Ali Al-Amoudi, and the ruling TPLF party (CSA, 2003; Hansson, 2004; Demissie, 2008).

From the total number of enterprises privatised, MIDROC (Mohammed International Development Research and Organization Companies), owned by Sheik Al-Amoudi, took the lion's share by obtaining around 60 percent of all privatised enterprises (Wikileaks, 2008). ${ }^{3} \mathrm{He}$ has developed a cosy relationship with the politicians of the regime, which culminated in the open support to the ruling party in the 2005 general elections. According to a US embassy cable, Al-Amoudi 'has cherry-picked the best of the companies sold to date'. For example, Legedembi is the only large-scale gold mine in the country, and Wushwush is the sole plantation-style tea producer' (Wikileaks, 2008). The Legedembi gold mine purchase in August 1998 (worth 172 million USD) was one of the most controversial privatisation deals involving MIDROC Gold Company (Kebede, 2014). Not only the modality of the transfer of ownership and privatisations by the party-state to Al-Amoudi was controversial but also the payments and loan arrangements benefiting the sheikh captured the attention of Ethiopian media. It was reported that MIDROC has arrears totalling 1.3 billion Birr, which amounts to 60 percent of what the Ethiopian Ministry of Public Enterprises had wished to receive for privatised entities (Fortune, September 2016).

The other primary beneficiary of privatisation is the ruling party, which has been in power for the last 25 years and has used its endowment companies to acquire privatised entities (e.g. Demissie, 2008). Significant numbers of enterprises were transferred to the party and its elites. The business arm of the ruling party grew together with the privatisation programme run by the party-state (see further below).

\section{Land expropriation}

Urban land for construction of properties and rural land for agricultural investments constitute the dominant source of wealth accumulation in post-1991 Ethiopia. Both urban and rural land have become critical resources that are serving the politicians very well. Bekele Gerba, one of the country's important opposition leaders, spoke the following famous words in a televised election debate:

As stated in the Ethiopian constitution and as stipulated in the policy document of the ruling party, the land belongs to the state and the people. But does the land belong to the people? Does it belong to the state? To both? The land belongs to no one but rather belongs to the ruling party officials. The ruling elites do whatever they want with it - they sell it, exchange it, get a friend with it, distribute it among relatives, and it serves as a seduction to recruit party members. Land has even become a tool to blindfold the educated, not to speak about justice, rights and equality [...]. Today, land is a space- 
shuttle that the few use to skyrocket to unprecedented wealth with the speed of light (EBC, 2010, authors' translation).

Gerba emphasised that, under the EPRDF regime, land has become a critical source of wealth for politicians and politically-connected business people. Land has become expensive and the new rich are now buying land at prices that surpass the value of the land. Stebek $(2015,67)$ has noted that this is 'a wakeup call regarding the level of lease tender price hike bubbles that can occur in a highly imperfect market'.

As for rural land, the nexus between the domestic land-grab and political connections is not difficult to see. For example, the Ethiopian government award of millions of hectares of land to investors in Gambella region commenced in 2008 to boost economic benefits (Oakland Institute, 2011). This study of Oakland Institute $(2011,23)$ indicated that, although most media attention to land grabs in Ethiopia was related to foreign acquisitions, domestic land deals are critical as 'the vast majority of investors (by some accounts, 95 percent) are domestic and account for more than half of the land area leased to investors'. These 'domestic investors' belong to the TPLF-related Tigray ethnic group and consist of politico-military elites and their close affiliates (Oakland Institute, 2011, 23-24). An observer has indicated that 'similar stories of massive acquisition of public resources unjustly acquired throughout Ethiopia by TPLF and 'Tigrians affiliated with the regime are widely circulated' (Zeleke, 2016).

\section{Phoney Shareholding}

The emergence and expansion of party-parastatals is another feature of the political economy of oligarchy in EPRDF's Ethiopia. Party-parastatals - or 'endowments' in their household name were mentioned frequently by key informants ${ }^{4}$. Although the proponents of the Endowment Investment Groups (EIGs), such as Arkebe Oqubay (2015), categorically deny that these businesses belong to the political party, data point in a different direction. The EIGs make EPRDF the richest party in Africa (Abegaz, 2011). The EPRDF is constituted by four political parties, and each of them has a business arm in the economy. Different from the West, Ethiopia's ruling party controls a large part of the economy and its core party TPLF is successfully presiding over a business conglomerate named EFFORT (Endowment Fund for the Rehabilitation of Tigray), established in 1995 (Milkias, 2003, 41).

TPLF politicians, especially shareholding central committee members, lead the companies as board members and CEOs. Independent government organs have not obtained the right to audit the endowment companies. Through the endowment companies, members of the political elite enrich themselves and exert enormous influence in the economy (Milkias, 2003, 45). Through its ownership of 14 different companies, EFFORT is investing in a variety of activities in manufacturing, services, merchandise, construction, mining and agriculture (EFFORT, 2016). Next to these investment activities, EFFORT has become a major shareholder in many more companies.

In his extensive memoirs, Legesse $(2016,215)$ uncovers that the political elite and their relatives managed to extract substantial wealth from the TPLF business conglomerate. Public enterprises were given away to EFFORT for small or no monetary compensation under the leadership of Assefa Abreha, head of the privatization board. The public enterprises included Kuraz 
Publishers, the historical publishing house established under Ethiopia's military regime, and EDDC (Ethiopian Domestic Distribution Corporation), which was acquired by EFFORT's subsidiary, Guna. Kuraz became Mega, EDDC became Guna, and the process continues in which public enterprises change hands from the state to party businesses and individuals. The expansion of the EFFORT's business interests, and consequently the shareholding adventures of the politicians, has grown exponentially. It is important to note how TPLF's business empires are intertwined (see also Assefa, 2003; Hansson 2004).

The various businesses that belong to the ruling party were established mainly through acquiring capital and assets though a variety of illegal and semi-legal means (Legesse, 2016, 185-226). These include loans-turned-uncollectable, transfer and plunder, fraud and semi-legal activitiess, business coercion, collusion and networking. As for loans, the lion's share (5 billion Birr) of the 8.5 billion Birr in loans given out by the Development Bank of Ethiopia (DBE) since 1991, was given to the Tigray region and its flagship company, EFFORT. Transfers and plunder included the looting of banks and channelling of aid to party coffers during the armed struggle, direct financial transfers from government bureaus to the party, and the transfer of physical and other assets from the state to party businesses. Oft-cited examples of such transfers are the emergence of Walta Information Centre and Radio Fana as important media companies, and their acquisition of the building and audio-visual archives of Ethiopian Television. These two media outlets are the cash-cows of the party and its main propaganda machines. Frand and semi-legal activities concern, among others, the inappropriate waving of taxes for importing vehicles and spare parts by EFFORT, which costs the state hundreds of millions of Birr. Coercion is applied as an instrument to secure assets and profit. The coercive capacity is built on the capture of key positions in ministries and boards that occupy critical roles in the economy. ${ }^{5}$

Collusion and networking are used as important instruments for the creation and maintenance of party businesses among the companies owned by EFFORT, thus creating synergies that aimed to control the 'value chain' in markets. The typical practice is that newly established companies create a chain of other companies, in which they are shareholders. Some members of the political elite obtain a small share in those new companies, and continue to lead the companies. Further, various TPLF businesses have created joint ventures with successful Ethiopian and foreign businesses, with the purpose of 'literally squeezing private businesses out of existence' (Milkias, 2003, 46). Though the legitimacy and role of the party businesses in Ethiopia have been criticised and questioned by many, they continue to grow in various sectors and their economic muscle is getting stronger. The most forceful push in this regard (yet again) was the establishment of another conglomerate, Dejena endowment, after the 2005 Ethiopian elections. Dejena is made up of six companies, most of them focusing on agriculture: Berhu Tesfa Plastic Factory, Michew Particle Board, Dema Honey Production, Alage Forestry and Forest Products, National Geotextile, Abergele Animal Fattening and Export. Dejena eventually became a subsidiary of EFFORT.

\section{Corruption}

The capture of wealth by EPRDF elites does not take place only through the practices discussed above but also through entrenched corruption practices, which show the nexus between political positions and business power. Corruption cases are compelling examples that demonstrate the 
concentration of wealth among a limited number of actors. The regime has itself confirmed the existence of corruption networks involving politicians and business people, but only a few cases were brought to justice. Some of the important corruption cases are discussed in this section.

\section{Customs and tax}

A high-profile corruption case in relation to tax and import-export trade reveals the collusion of politics and money, especially in the booming service sector. The corruption case, which was started in October 2013, led to the indictment of more than 65 individuals ranging from the Director General of the Ethiopian Revenues and Customs Authority to other high ranking officials and their relatives, business people, and freight forwarders (FEACC, 2014; Fortune 2013, various issues). The charges against customs officials relate to, among others, 'allowing goods to pass through customs uninspected' (FEACC, 2014). These practices involved prominent business companies such as Nyala Motors, Petram Plc, Moenco, GET-AS Trading, Alsam Plc, METEC, Ayka Addis Trading, MIE, Holland car, Total Ethiopia, MIDROC, Salini Construction, Dire International trading, Ethio-leather, Basefa Trading Plc, GETAS international, and Comet Trading House (FEACC, 2014). The business people were charged for 'tax evasion through graft', 'importing through illegal means' and 'selling duty-free imports meant for investment' (FEACC, 2014). The amounts of money involved in these tax evasion scandals are enormous compared to the size of the economy (for example, tax evasion by just three individuals involved more than 300 million Birr). The indictment process has also shown the corruption networks that involved customs officials and their relatives, the business companies and tax officials.

\section{Security apparatus}

The secrecy and entrenched corruption within the security apparatus have been exposed by some media outlets as well as our respondents (see for example Ayalew, 2016). The most prominent case in the security apparatus brought to justice by the regime is that of Mr Woldeselassie Woldemichael and his co-defendants. This security chief is known for his brutality and entrenched corruption networks but the first charge filed in January 2014 by the Federal AntiCorruption Commission relates to the abuse of his position as a security officer and member of different boards of public enterprises. He used his access to coerce public printing presses to publish 13,000 copies of a book titled Terrorism in Ethiopia and the Horn of Africa. Then he 'sold' the copies to public enterprises and to twenty-six major businessmen in the country, although the book was irrelevant to their work. The charges highlight the involvement of the business community and their subjugation to the political and security apparatus of the regime. Further, the charges demonstrated how high-profiled security official Woldemichael and his family had become millionaires over a short time span, having become the owners of two major farming companies as well as large amounts of assets and cash. 
The case of Tamrat Layne, which dates back to the mid-1990s, was the first high-profiled corruption case in Ethiopia. Tamrat Layne was Prime Minister of Ethiopia during the transition period in the early 1990s and later became Deputy Prime Minister and Minister of Defence. He was charged with abuse of power, embezzlement and corruption. He was eventually found guilty of the charges and was sentenced to 18 years of imprisonment. One of the major charges brought against Layne concerned the solicitation of a gift of US \$16 million USD from Sheikh Al Amoudi to the Ethiopian government, part of which was allegedly misappropriated by Layne. Further, charges against Layne related to his intervention in a contract involving the supply of building materials, which was awarded to Ramis International, whose shareholders included, among others, Tamrat Layne's mother (Indian Ocean Newsletter, various issues).

\section{Conclusion}

Private ownership, which had been abolished by the military-socialist regime in 1974, came back to life in 1991 when EPRDF took power, although in a different shape. Under EPRDF rule, Ethiopia has been growing fast and wealth commenced shaping the character of politics. Economic growth has been trumpeted by the World Bank and IMF as miraculous and yet the country fails to address basic needs of millions of its people. The country's reliance on food aid has ranged from 8 to 18 million people annually since 2005, making Ethiopia the largest recipient of food aid in the world (Oakland Institute, 2016). Seen against this background, the signs that wealth is increasingly concentrated among the politically well-connected elite call for a sober reflection.

The country's political-economy dynamics, revolving around politics, business and wealth creation, is possibly leading Ethiopia into troubled waters, where the toxic mix of ethnicity, business, and official power is evident. This complex of issues is one of the most urgent matters that the country is grappling with. The economic growth, accompanied by urban and rural land expropriation, fraudulent privatisation, corruption and politico-business collusion, has facilitated oligarchy formation since the 1990s. The implication of this oligarchisation is that it has changed the nature of politics in the country. Widening inequality, as oligarchic theory predicts, has led to the emergence of a disenfranchised majority, on the one hand, and the search for new instruments of wealth defence by the few, on the other. These dynamics have changed the character of the Ethiopian economy, particularly related to business and work ethics of the young and upcoming entrepreneurs. The possiblity for people to move up in the wealth hierarchy is dependent on political networks and blood ties. As Bulcha (interview, October 2015) pointed out, 'If someone is a smart industrialist who has proven himself in other countries and came to Ethiopia to invest and he is not a friend of the government, he cannot continue to be wealthy.' Post-1991 Ethiopia is not a simple pyramid with a few rich at the top and millions of poor at the bottom, but has turned into a state-sponsored chain of ethnically-tilted capitalist relations where party-related companies grow wealthier, seconded by 'yes-men business people' who benefit from public funds and projects. 


\footnotetext{
${ }_{1}^{1}$ According to Minister Abraham Tekeste, the 17 years of the military regime, after the fall of Emperor Haile Selassie (1974-1991), witnessed an annual average growth of 1.9 percent. In that period, population growth was 3 percent annually, which implied an annual decline of per capita income of 1 percent. The Minister claims that currently 'the people are benefiting from the growth and the sense of fatalism of the old days has gone' (interview 28 April 2016).

2 According to the now defunct Privatisation and Public Enterprises Supervising Agency (PPESA), the programme has privatised more than 90 small-scale wholesale and retail shops, 37 state farms, 34 hotels, 31 food enterprises, and 19 textile enterprises. The rest are in manufacturing, chemical, metal and woodwork, beverages, leather industries, et cetera.

${ }^{3}$ Sheik Al-Amoudi is the wealthiest oligarch in Ethiopia, with possessions totaling around US\$10 billion (Abegaz, 2011). Forbes (2017) has recently listed the Sheik as the 43rd richest person in the world.

${ }^{4}$ The key informants are business people, public intellectuals, journalists and others who were interviewed in 2015 and 2016 in Ethiopia within the framework of a PhD study on the subject.

${ }^{5}$ Office holders use their powers to coerce companies in which the government is a shareholder to sell low-priced products to party companies. The most famous case was brought to light during the corruption trial of the former Defence Minister. The trial showed that politicians coerced AMICE to sell trucks to EFFORT, at low prices, and transfer some 42 trucks for free. The story is detailed in the political memoir of the former Defence Minister Siye Abraha himself titled, Netsanetna Dagninet be-Ethiopia [Freedom and Due process of law in Ethiopia].
}

\section{References}

Abegaz, B. 2011. "Political Parties in Business". Department of Economics Working Paper 113. Williamsburg: College of William and Mary.

Åslund, A. 2007. How Capitalism Was Built: The Transformation of Central and Eastern Europe, Russia, and Central Asia. Cambridge: Cambridge University Press.

Assefa, B. 2003. The Trade Empires of the Tigray People's Liberation Front (TPLF) and EPRDF. Addis Ababa. (written in Amharic).

Ayalew Mengesha. 2016. "The Structure and Activities of the Ethiopian Intelligence and Security Agency”. Retrieved from https://youtu.be/sZXetoQyDn8.

Cheru, F. 1989. The Silent Revolution in Africa: Debt, Development and Democracy. London: Zed.

CSA (Central Statistical Agency). 2003. "Report on Large and Medium Scale Manufacturing and Electricity Industries Survey”. Statistical Bulletin 281, October. Addis Ababa: CSA.

Demissie, F. 2008. "Situated Neoliberalism and Urban Crisis in Addis Ababa, Ethiopia". African Identities, 6(4): 505-527.

EBC. 2010. "Live Election Debate on the Ethiopian Television". Retrieved from https://youtu.be/YY4EuwFNO 8.

EIC (Ethiopian Investment Commission). 2014. "Ethiopian Investment Guide 2014. Ethiopia: A Preferred Location for Foreign Direct Investment in Africa". Retrieved from http://www.investethiopia.gov.et.

FEACC (Federal Ethics and Anti-Corruption Commission). 2014. "Corruption Charges Submitted to the Federal High Court". Internal document (in Amharic).

Hagmann, T. and Abbink, J. 2011. "Twenty Years of Revolutionary Democratic Ethiopia: 1991 to 2011." Journal of Eastern African Studies, 5(4): 579-595. 
Hansson, G. 2004. "Ethiopia, Performance and the Role of the Private Sector". SIDA Country Report 4. Lund: SIDA.

Indian Ocean Newsletter. Various issues from 1991 to 2016.

Kawabata, M., 2006. “An Overview of the Debate on the African State”. Working Paper 15. Afrasian Centre for Peace and Development Studies, Seta: Ryukoku University.

Kebede, E. 2014. "Privatization and its Challenges in Ethiopia" (blog), 14 August. Retrieved from http://nazret.com/blog/index.php/2014/08/21/privatization-and-its-challenges-in.

Legesse, E. 2016. “Ye Meles Likakit”, Netsanet Publishing Agency (published in Amharic)

Markus, S. and Charnysh, V., 2017. "The Flexible Few: Oligarchs and Wealth Defense in Developing Democracie”. Comparative Political Studies, 50(12), pp.1632-1665.

Milkias, P., 2003. "Ethiopia, the TPLF, and the Roots of the 2001 Political Tremor". Northeast African Studies, 10(2), pp.13-66.

MoFED (Ministry of Finance and Economic Development). 2014. "Brief Note on the 2007(EFY) NAS Estimates (The major results of the 2007 GDP estimates)”. Internal document.

Oakland Institute. 2011. "Understanding Land Investment Deals in Africa. Country Report: Ethiopia”. Oakland: The Oakland Institute.

Oakland Institute. 2016. "Miracle or Mirage? Manufacturing Hunger and Poverty in Ethiopia". Oakland: The Oakland Institute.

Oqubay, A. 2015. Made in Africa: Industrial policy in Ethiopia. Oxford: Oxford University Press.

Reporter. 2016. "Stakeholders Urged to Resolve Construction Sector Snags", 17 December.

Seid, Y., Taffesse, A.S. and Ali, S.N. 2015. "Ethiopia: An Agrarian Economy in Transition." WIDER Working Paper 154. Helsinki: UNU-WIDER.

Stebek, E.N. 2015. "Challenges in Access to Urban Land for Business Activities under Ethiopian Law: Between Oligarchy and Broad-based Private Sector." Mizan Law Review 9(1): 37-82.

Van Hoyweghen, S. and Smis, S. 2002. "The Crisis of the Nation-state in Central Africa: A Theoretical Introduction." Review of African Political Economy 29 (93/94): 575-594.

Wikileaks. 2008. "Privatization or Monopolization in Ethiopia?” Retrieved from https://wikileaks.org/plusd/cables/08ADDISABABA82 a.html.

Winters, J.A. 2011. Oligarchy. Cambridge: Cambridge University press.

World Bank. 2016. "Ethiopia's Great Run: The Growth Acceleration and How to Pace It". Retrieved from http://documents.worldbank.org/curated/en/693561467988949839/pdf/99399REVISED-PUBLIC-thiopia-Economic-Update-2-11-16-web.pdf.

Zeleke, N. 2016. "Ethiopia: The Myth of a Stable and Reliable Partner under the Minority TPLF Regime", 29 September 2016. Retrieved from http://www.ethiomedia.com/1016notes/7583.html. 
